\title{
Naïve Justice in the Ancient Greek Novel
}

\author{
Bruce D. MacQueen \\ (University of Tulsa, bruce-macqueen@utulsa.edu)
}

\section{Introduction}

It is admittedly a commonplace, but probably a useful one, to begin a philosophical discourse by dividing the problems into three main areas of inquiry: ontology, epistemology, and ethics. This division is usually attributed to the Greeks, but it is no easy task to trace it to its origins. Applying it to the dialogues of Plato might or might not shed some light on some of the dialogues and their arguments, but in many ways it seems an unnecessary distraction, especially since Plato seems bent, generally, on synthesizing the philosophical enterprise into a coherent unity. Aristotle, the perpetual analyst, in the course of discussing some problems related to dialectic, makes an important contribution to this general problem, in order to render more manageable the specific problem

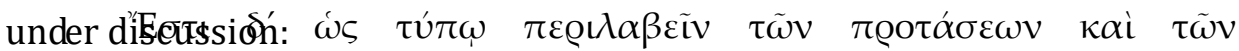

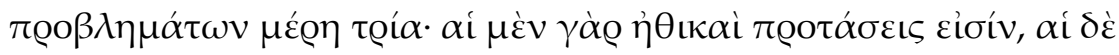

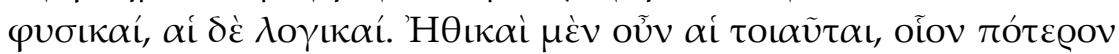

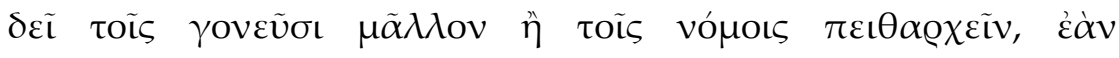

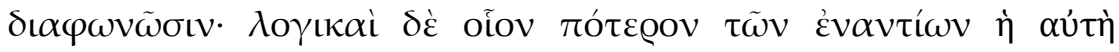

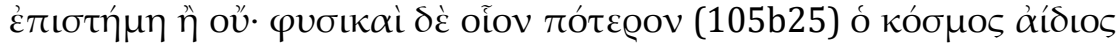
ทे oú.

It is possible to distinguish by type three kinds of questions and problems: some are ethical questions, some are physical, some are logical. Ethical questions are such as this, whether one ought to listen to one's parents or to the law, if they are at odds; logical questions are such as this, whether the knowledge of opposite things is the same, or not; physical questions are such as this, whether the universe is unending, or not (Topics 105b19-25, translation mine).

Later, in Stoic philosophy, Aristotle's "logical" questions are broadened in scope and renamed "epistemology," and the "physical" questions, analogously, become "ontology." This tripartite division of genres in philosophical inquiry was bequeathed, as it were, to philosophical posterity, where, as mentioned at the 
beginning, it has become a commonplace. Ontology, then, consists in a philosophical inquiry into being, while epistemology examines the nature of knowledge and the mind, and the goal of ethics is to explore behavior, or more specifically, how philosophy could or should guide moral choices. The goal of ontology is to understand being and non-being; of epistemology, to understand what is true and what is false; and of ethics, to distinguish right from wrong.

The operative ethical concept called "right" in English is encompassed

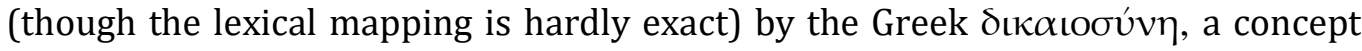
usually translated "justice" in philosophical texts, but "righteousness" in the New Testament. Herein, of course, lies the problem: where Greek authors can attribute $\delta 1 \kappa \alpha 10 \sigma u ́ v \eta$ to either individuals or societies without any sense of awkwardness or ambiguity, it seems distinctly odd, in English, to associate "righteousness" with the character of a society (a state, a community, a city), while "justice" is, if not inappropriate, then at least slightly odd, when applied an individual - unless, of course, the individual in question is a person of authority (a monarch, an official, a judge) making decisions on behalf of and in the name of the state. It may be

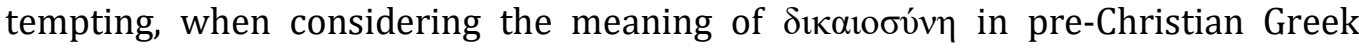
philosophy, to ignore "righteousness" and concentrate on "justice," but that is at best a convenient bracketing, not a solution.

We should acknowledge that, in reality, neither of those two English words,

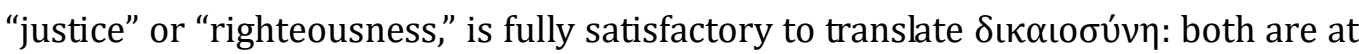
best partial renderings of what the Greek word means.

The problem is familiar to students of Plato. The first definition of

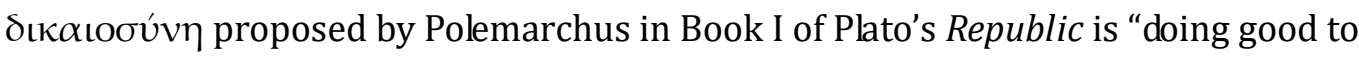
one's friends and harm to one's enemies," a conventional formulation that runs through much of archaic Greek poetry. When Socrates shakes his confidence in a definition that most Greek readers would have regarded as obvious, even selfevident, Polemarchus falls back on a second definition: giving back what is owed. Neither of these two definitions, to English ears, sound like definitions of "justice" at all, since these are matters of ethics - that is, determining what is right - rather than political philosophy. Thrasymachus's definition, on the other hand (justice is whatever is consistent with the interests of the stronger) seems more public and political, which makes it, though arguably morally abhorrent, at least 
comprehensible as a definition of "justice." If Polemarchus was attempting to find a principle or axiom that would explain what is right, Thrasymachus is at least trying

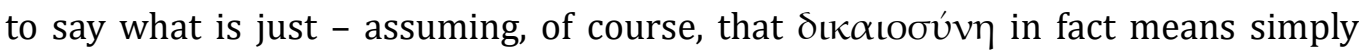
"justice," which is precisely the point at issue here. The assumption can hardly be forced. The transition from Polemarchus to Thrasymachus as Socrates' interlocutors

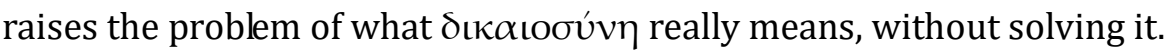

In Book II, then, Socrates proposes to search for the essence of this particular virtue in the soul, by expanding the scale of inquiry to the level of the city. This maneuver can seem almost indefensible to a critically-minded English speaker, but it makes much more sense if we accept that the Greek word which Socrates and his friends are out to define is a single concept that can be manifested in both public

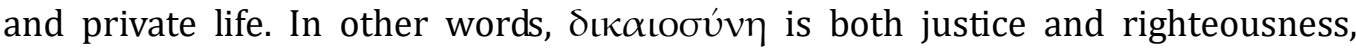
public and private "rightness," rolled into one.

The purpose of this article is to examine, from an ethical perspective, an apparently trivial topos of the ancient Greek novel: the "trial scene," in which one of the protagonists is accused of a crime and put on trial, but ultimately prevails against a determined prosecution. Specifically, I will present here three such episodes, which diverge from the model just described, in ways that serve to shed

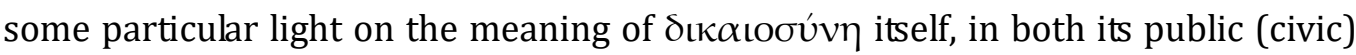
and private (personal) senses. Before this will make much sense, however, we shall need to go, as Socrates puts it, "by the longer road."

In a famous passage from the Poetics (1452b - 1453a), Aristotle considers the types of plots that should be considered properly "tragic." He rejects as untragic

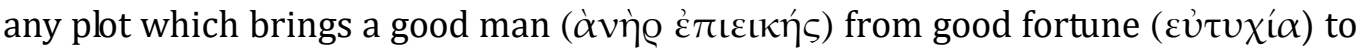

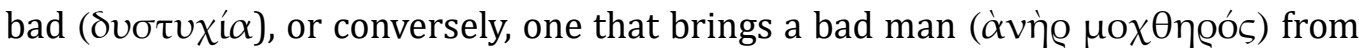

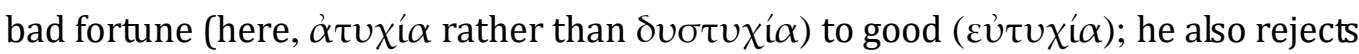

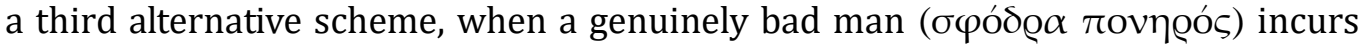

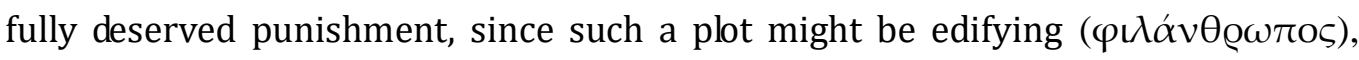
but inspires neither pity nor fear, and is thus not tragic. This line of reasoning leads him to the famous definition of the tragic hero, which he presents as a middle point (ó $\mu \varepsilon \tau \alpha \xi \dot{v} \tau o v ́ \tau \omega v$ ): that is, a man not preeminently virtuous or just, who is 
brought from good fortune to bad, not by innate wickedness, but because of some

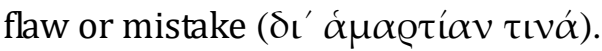

After some development of this argument (with particular attention to Euripides), Aristotle then takes up what he calls the "double structure," which is to say, a plot that simultaneously brings the virtuous to good fortune and the wicked to bad fortune. This paragraph (often overshadowed completely by the "tragic flaw" discussion that immediately precedes it) requires closer attention here:

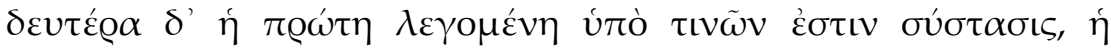

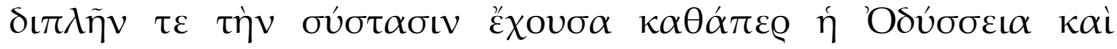

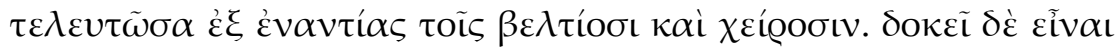

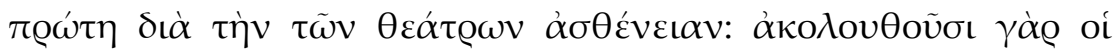

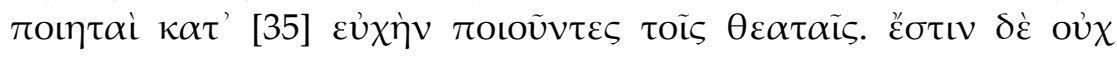

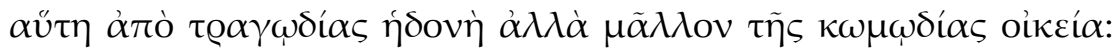

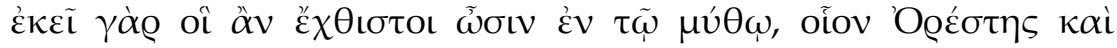

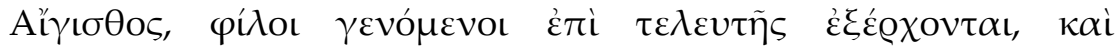

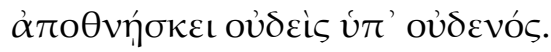

Second [viz. in order of preference] is the structure that some call first, the one which has a double structure, like the Odyssey, and ends in the opposite way for the better and worse characters. It seems to be first because of the weakness of the theaters: for the poets give the audience that which they demand. This is not the same pleasure as from a tragedy, but rather something similar to comedy: for there, those who are bitter enemies in the myth, such as Orestes and Aegisthus, come out as friends at the end, and no one is killed by anyone (Poetics 1453a, translation mine).

The kind of plot Aristotle seems to hold almost in contempt here, as though it were simply pandering to $\alpha \sigma \theta \varepsilon \dot{v} \varepsilon\llcorner\alpha$, is something I shall call here, for convenience's sake, "naïve justice." Good things happen to good people, and bad things to bad people, and all is well in the world (though this is always so much easier to do in fiction than in reality). For the present purposes, then, I propose to examine this problem, not from the perspective of standard philosophical discourse, but rather from a perhaps unexpected source: the ancient Greek novels, the popular literature of late antiquity. Philosophers, traditionally, do not listen much to the vox populi, but there are times, pace Socrates or Aristotle, when there may well be something to be learned from the "weakness" of the masses. 
The ancient Greek novels - five of which are extant - are a product of the last centuries of pagan Greek literature, from the first to the fifth century CE, and until rather recently have not been the object of much serious study. Nietzsche regarded them with contempt, since in his view they were the opposite of the tragedy he so much admired: rather than embracing the inevitability of death, they pandered to the readers' desire to imagine that death could be evaded. Nietzsche's sometime friend, the classical scholar Erwin Rhode, wrote a book, perhaps in explicit or implicit answer to Nietzsche's critique, on the ancient Greek novel (Rhode, 1876), but he made no case that these works displayed any particular literary or (even less) philosophical merit. Almost a century later, Ben Edwin Perry (1967), though he rejected Rohde's theory in detail, called the putative readers of these unassuming works the "poor-in-spirit," perhaps unconsciously echoing Aristotle's remark about the $\alpha \sigma \theta \dot{\varepsilon} v \varepsilon\llcorner\alpha$ of the theater-going public. Perry's belittling characterization of the readership of the ancient novel has since been attacked (see, inter alios, Anderson, 1982; MacQueen, 1991), but it is hard to avoid the impression that most, if not all of these five texts are addressed to a much broader and presumably far less sophisticated audience than the philosophical texts of classical and Hellenistic Greek literature.

At first glance, these texts may indeed seem to have been the Harlequin romances of their day, and as such not to merit any sort of close reading. The form of composition seems thoroughly generic - that is, the individuality of each of these novels mostly comes from the way a given author orders, manipulates, and combines plot devices and characters that are already familiar from other works belonging to the same genre. The twists and turns of the particular plot, though elaborate, seldom deviate far from the basic plotline: a handsome young man and a beautiful young woman meet, fall in love, but must pass through numerous adventures and ordeals before the story ends on a note that can hardly be otherwise described than by saying, "and they lived happily ever after." These adventures and ordeals are the main topoi from which the story is built, and, as most scholars now agree, show too many points of contact with the New Comedy of Menander for this to be entirely coincidental (Anderson, 1982).

It would be digressive here to pursue this characterization of the genre much further, especially because much recent scholarship on the individual novels 
(including my own modest contributions) has tended to suggest that at least some of these authors may deserve more respect than they have heretofore been afforded. Rather, I propose to single out one topos of perhaps obvious interest to ethicists: the trial scene. With some variation, this plot device is not unfamiliar even to modern audiences, in one form or another. The hero or heroine is falsely accused of a crime (typically, they have been framed by a wicked character, often a rejected lover) and put on trial (mostly public, but sometimes before a king or other high public official); but then, just when the preponderance of hostile testimony seems to doom the hapless defendant to certain conviction and execution, the tables are turned, and the hero or heroine is exonerated. Typically, the wicked prosecutor then suffers the very fate intended for our hero or heroine.

As plot devices, these scenes can be compared to another common topos, usually called Scheintod, which involves one of the two romantic partners being given reason to suppose that the other partner has died. When the grieving reaches its greatest intensity and has become all but unbearable, it is revealed that the partner is in fact not dead, so that grief gives way, suddenly, to joy. In both topoi,

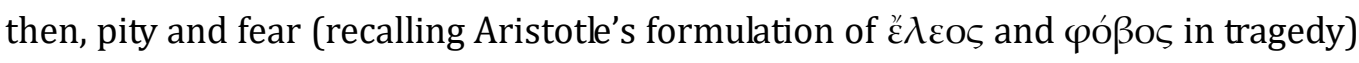
are deliberately aroused in the reader, only to be assuaged in short order by the happy outcome. The apparent intention of these authors to achieve just this effect is exactly what prompted Nietzsche's disdain for the entire genre. Modern popular literature (including, of course, film and television fiction) are similarly inclined to construct plots built around suspense and reversal, in order to arouse as much emotion as possible, without leaving the reader (viewer) for very long in the grips of pity and fear.

There are three trial scenes in these novels, however, that upon closer inspection can actually be said to subvert the "asthenic" model just described. These are the following:

(1) the trial of Chaereas in Chariton's Chaereas and Callirhoe, which occurs at the end of Book I;

(2) the trial by ordeal of Leucippe in Achilles Tatius's Leucippe and Clitophon, which occurs in Book VIII, and constitutes virtually the last major incident of the novel; 
(3) the impromptu trial of Daphnis in Longus's Daphnis and Chloe, which occurs in Book II and serves to trigger a number of incidents central to the novel.

\section{The Trial of Chaereas}

The two young lovers of Chariton's novel meet, fall in love, and marry before the first book of the novel is over, and in due course Callirhoe is pregnant. The misadventures begin when a group of disgruntled former suitors manage to convince Chaereas that the child is not his. In a rage, he kicks Callirhoe in the stomach, which causes her to fall senseless to the floor, to all appearances dead. After a funeral described in great detail, Callirhoe, still as beautiful as though she were alive (of course, she is really only in a coma) is laid to rest in a tomb that has been carved into cliffs overlooking the sea. When a notorious grave robber named Theron breaks into the tomb to plunder it, he and his accomplices are astounded to find there a beautiful and very much alive and alert young woman, who has awakened from her coma; seeing a great profit to be made on the slave market, they take her away.

In the meantime, Chaereas's father (whom the novelist has identified at the very beginning of the novel as none other than Hermocrates, a very real historical person, the Syracusan general who brought about the destruction of the Athenian expedition in the single most crucial battle of the Peloponnesian War) brings charges against his son-in-law for the unlawful killing of his daughter. Chaereas, however, is so consumed by remorse and grief that not only does he refuse to defend himself, but he actually becomes his own prosecutor. Hermocrates, for his part, moved by the depth of the young man's grief, changes his mind and tries to persuade the court to show leniency. In the end, Hermocrates wins and Chaereas is spared execution for murder. The young widower, however, is inconsolable, and uses his freedom only to go down to Callirhoe's tomb, intending to kill himself over her dead body. When he arrives, he discovers that there is no body, and from the physical clues deduces that she has been taken by pirates. He sets off to find her, and the adventures begin. 
The irony of this particular trial scene (which occurs early in the first book of the oldest extant Greek novel) lies of course in the fact that the victim of the murder is not in fact dead, and that the prosecutor becomes the defender, while the defendant becomes the prosecutor - of himself. Moreover, even allowing for the notorious Greek tolerance for domestic violence, it is hard to excuse what Chaereas has done. In fact, his self-prosecution is absolutely correct as far as the law is concerned. He has done that which he is accused of doing: without sufficient reason or justification, he has committed an act of physical violence that has (apparently) caused an innocent person to die. Some readers may be swayed by the arguments of Hermocrates, who bases his arguments on the absence of malice, apparently assuming that, if Chaereas' suspicions regarding Callirhoe's pregnancy had been correct, his attack on her person would have been justified. But it takes more than that to really excuse what Chaereas has done.

This is hardly (at least at this point), the "double structure" held in such contempt by Aristotle. The roles of the "better" and "worse" parties in the trial are hopelessly confused: however much an audience may feel sympathy for Chaereas, the facts are against him, and so is the law, which in any reasonable moral calculation makes him the "worse" party. Hermocrates, the prosecutor, seems to be rather the opposite of the malicious slanderer who is stereotypical for trial scenes: the case he has brought against Chaereas is fully justified, and his decision to argue for mercy is the precise opposite of the "frame up" strategy used by prosecutors. As for the change in fortunes: Chaereas is acquitted but is consumed by guilt, and intends to inflict upon himself the same punishment, death, which the court refused to order. Hermocrates, a loving father who has lost his beloved daughter, denies himself the satisfaction of seeing her killer brought to justice by "switching roles" and saving his life.

The fact that Callirhoe is not actually dead, and will ultimately be rescued and brought home by the self-accused killer (to the great joy of the entire populace, and especially Hermocrates), does not actually change the ethical and jurisprudential quandaries of the trial and its verdict. The sufferings that Chaereas endures in searching for his wife, which extend even to crucifixion (from which he is miraculously saved), may in a sense even the score here between husband and wife, but one wonders what a woman in the fictional Callirhoe's place would 
actually have thought and felt when she returned, finally, to her home - where her husband had kicked her, pregnant, in the belly, the last time they were together there. What could the husband say, in that case, that would actually change anything? The ancient Greeks, of course, may have had a very different moral compass when judging the relations between men and women, but the ancient Greek novels are themselves filled with indications that attitudes were changing, even if contemporary ideals of gender equality could hardly have been so much as glimpsed in the first century of our era.

Whatever this is, it is not "naïve justice."

\section{The Trial of Leucippe}

What I have here called "the trial of Leucippe" is in fact part of a much larger and more elaborate trial scene that occupies most of Book VIII in Leucippe and Clitophon. A merchant named Thersander, who has gained possession of Leucippe and is holding her as his slave, has hidden her from public view, and then accused her lover, Clitophon, of murdering her. Clitophon, believing her dead, is so distraught that he fails to defend himself, intending to die, even though he knows himself to be innocent of her death. As in the previous case, here, too, Leucippe is not dead at all: just when Clitophon has been found guilty and condemned to death (to his own perverse satisfaction), she is produced in court, alive, to demonstrate Clitophon's innocence. Rather than concede, however, Thersander insists that Leucippe is a harlot slave, not a freeborn woman, and that Clitophon has been lawfully condemned to death and must be executed. After some tortuous legal wrangling, the decision is made to test Leucippe's virginity, which according to local tradition is done by sealing her up in a grotto sacred to Artemis, where a set of divine Pan pipes are hanging. If she is indeed a virgin, the pipes will spontaneously sound a high, clear note, but if not, there will be a groaning sound. In the latter case, the woman under examination will be sealed up in the grotto and left to die. At the same time, Clitophon's would-be lover and Thersander's wife, Melitte, is challenged for her fidelity to her husband, and this comes to be an essential part of Thersander's case against Clitophon. The ordeal used to settle this issue, also a local tradition, involves the woman writing her oath upon a tablet and stepping into a certain sacred pool, 
where the water is up to her knees; if she is telling the truth, the water stays where it is, but if she is lying, then the water rises and boils around her head.

Leucippe is placed in the grotto, and a high note is heard, so she is released to general rejoicing, while Thersander is reviled by the crowd of bystanders. Then Melitte, likewise, passes her ordeal. Thersander, fearing the wrath of the people, flees into self-imposed exile, while Leucippe and Clitophon are reunited and journey on.

The central irony of all this involves the question of whether either of these women is actually innocent of the charges brought against them. In fact, Leucippe and Clitophon have tried several times already to consummate their love, but on each instance they have been foiled; in fact, all their adventures had begun, in Book I, when they were discovered together, in Leucippe's bedroom, in a compromising position, by her mother, and fled through the window to escape her wrath. Leucippe, over the course of the preceding seven books, has been in the hands of pirates and other men of less than admirable moral character; and while the text is very coy about revealing whether or not her virginity is actually intact, Clitophon cannot be sure - and neither are we - how Leucippe's ordeal will end. He is filled with anxiety when she enters the grotto, an anxiety he would scarcely have felt if he had been confident of her virginity.

The case of Melitte is even more striking, since she has indeed had sexual relations with Clitophon, as we know from Book VI, so that her oath of marital fidelity is quite false - though Clitophon never tells Leucippe the truth about all this. If the ordeal had gone as it was supposed to go, the water should have risen and boiled around Melitte, which would have revealed to everyone, including Leucippe, the fact that Clitophon had indeed slept with another man's wife, violating the rights of both Thersander and Leucippe.

Although a full treatment of all the ironies at work here in this novel would be unnecessarily digressive, for the present purposes it may be of use, in analyzing the subversion of "naïve justice" at play here, to mention two salient aspects of the story. To begin with, the novel is essentially a first-person narration by Clitophon himself, who, as Morales has pointed out (Morales 2001), is himself hardly a reliable narrator. The novel begins with a fairly brief introduction, in which an unnamed first-person narrator describes his chance encounter, in a temple in Sidon, with a 
young man who turns out to be Clitophon. The balance of the story is told by Clitophon, then, and in fact we never return to the temple in Sidon - which means, as the story draws to an end in Book IX, that we never learn why Clitophon is in Sidon, why he is apparently alone, and why he is so unhappy and so cynical about Eros at the moment when he first meets the narrator. Although it has seemed to many readers over the years that the work ends this way because it was never finished, more recent scholarship, summarized by Morales (2001), has inclined to the view that the structure, along with the inconsistencies and obvious omissions, is quite deliberate.

Secondly, the "back story" of Clitophon and Melitte raises many questions, even assuming that Clitophon is telling us the truth about what happened. In Book IV, Leucippe passes through what is in fact her second Scheintod scene, when Clitophon actually witnesses her being beheaded by pirates, who have kidnapped her. In fact, it was Leucippe's servant, dressed in her mistress's clothes, that the pirates beheaded, but Clitophon believes that the headless body he fishes out of the Nile is indeed his beloved Leucippe. Inconsolable, he wanders along the banks of the Nile for some time, slowly starving in his grief; but he comes to the attention of Melitte, the young wife of a prominent merchant, Thersander, who has been gone on a perilous journey related to his business for several years now, and is assumed to be dead. Melittle falls for Clitophon and determines to have him; after resisting her for quite some time, he finally agrees to marry her. Even after they are married, however, he remains faithful to his lost love and finds excuse after excuse not to consummate the marriage. Finally, Melitte accepts into her household a new slave woman, who is none other than Leucippe; Clitophon thinks he recognizes her, but refuses to believe that this slave is Leucippe until she writes him a note. Clitophon is overjoyed - but before he has decided what to do to gain Leucippe's freedom, he buys time by giving way to Melitte's pleading, and has sexual relations with her that is, he holds out until after he has learned that Leucippe is alive and near at hand. This explains why Clitophon knows, in Book VIII, that Melitte's oath of innocence is false, while Thersander's accusation of adultery against Melitte and Clitophon (he returns unexpectedly, of course, very much alive and very angry) is quite true. His guilty secret is shared, in some detail, with the first narrator, in Sidon, and thus with us as readers, but not with Leucippe. Perhaps we could speculate that 
the reason Clitophon is so forlorn at the very beginning of the novel may be precisely that Leucippe has discovered the truth and left Clitophon to return to her parents; but this is the part of the story, again, that Clitophon does not tell.

Although in many ways Thersander fills the criteria for the malicious prosecutor, in that he has framed Clitophon for a murder he did not commit, the situation as a whole is almost comically complicated, with the result that the ethical issues at play here are not easy to sort out. Thersander has indeed made a false accusation of murder - but he is also, in reality, a wronged man, and his accusations of adultery, despite the apparent verdict of the local oracles, are at least partially true. The framed defendant, Clitophon, is a liar and an adulterer. By the end of the

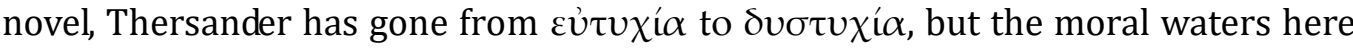
are so muddy that it is hard to defend the proposition that his self-imposed exiled is

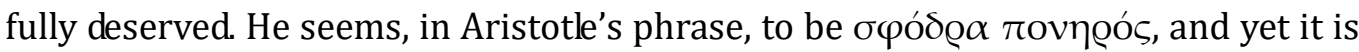
really his rage against Clitophon and Melitte, far more than his lust for Leucippe, that motivates him to frame Clitophon for murder - and that rage, even if not fully justified and not sufficient to warrant his behavior, is nonetheless not unmotivated. Clitophon, reunited with Leucippe, sails off to a happy life with her, which seems

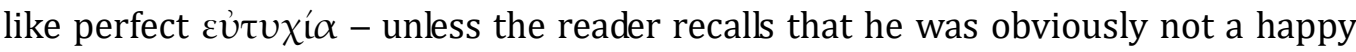
man when he began to tell the story. A case could perhaps be made - though this would take us too far afield for the present study - that by the time we connect the incomplete ending of his story with the beginning, and make some not unreasonable inferences, Clitophon becomes a sort of tragic hero, falling from good fortune to bad because of some mistake or flaw. But there is more than a little irony in this.

\section{The Trial of Daphnis}

In book II of Longus' Daphnis and Chloe (chapters 12-17), the young shepherd, Daphnis, is seized by a group of angry young men from Methymna, one of the two principal cities of the island of Lesbos (the other is Mytilene, in whose district the fields lie, where Daphnis and Chloe live and tend their sheep). The Methymnean youth are furious, because they have come on a hunting expedition by boat to the part of the island where Daphnis tends his sheep, and tied up their boat to a tree, 
using a rope of plaited vines. Daphnis's goats have nibbled the vines, breaking the rope, and the boat (which had, among other things, a bag full of money on board) drifted out to sea and was lost. The Methymnean hunters have decided to take Daphnis home with them as their slave, in compensation for their loss, but they are prevented by a crowd of locals, who insist on holding a makeshift trial (the verb

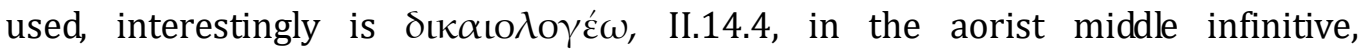

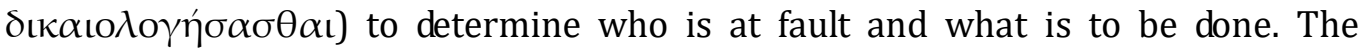
Methymneans argue that Daphnis was negligent in tending his goats, and that, since he is a slave (which indeed he is), they are entitled to his person in compensation for their loss, which is his fault. Daphnis, defending himself, reminds the "court" that they all know him and his goats, and ends his speech by bursting into tears. Without further ado, the locals free Daphnis and chase the young men away - which will lead, in Book III, to a punitive expedition from Methymna and a counterattack by Mytilene.

At first glance, this all seems somehow familiar and even comforting: a confrontation between spoiled, rich youth from the big city and hard-working, simple country folk ends with the tables turned on the rich. The problem lies in the fact that Daphnis is indeed guilty of neglect (he has been dallying with Chloe and not paying enough attention to his goats), and the Greek laws and customs applying to losses caused by the negligence of someone else's slave would have been rather clear. In his speech of defense, Daphnis simply appeals to the emotions of the "court," who are all his neighbors and friends, and ends in tears. Since he is the charming protagonist of a charming love story, Daphnis elicits sympathy, not only in this scene and not only from his neighbors, but throughout the novel and from most readers. This is not the only place, however, where there is an undertone of something else, a contrary judgement of his character (MacQueen, 1991, 2009) with a darker side.

In the definition of "naïve justice" used to this point, we have heretofore skirted an elementary question: what criteria should be used to determine who are the "better," and who the "worse" characters? The most primitive criterion here would be self-interest: anyone who does good to me is good, and anyone who harms me in any way is bad, where it seems obvious, if circular, to assume that whatever I like is right, and whatever I dislike is wrong. From here, it may seem an advance of 
sorts to something we might call "tribal justice," which uses the same formula for distinguishing right from wrong and good people from bad people, while replacing the first person singular with the first person plural: anyone who helps us is good, anyone who harms us is bad. In international politics, this kind of tribal justice clearly prevails to this day, even if there is some sense, in some people, at some times, in some ways, that perhaps there are or ought to be other criteria for right and wrong, good and bad.

The outcome of the "trial" of Daphnis, where the locals set themselves up as

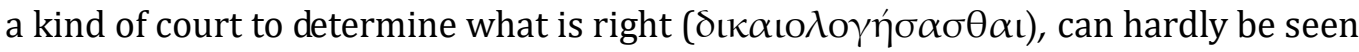
in any other way than as an example of tribal justice. The moral ambiguity of the whole situation will be lost on those whose own ideas of right and wrong are established in this way. Although this is not the time or place to pursue the interpretation of Longus's novel any further, suffice it to say that the present author, at least, is convinced that Longus means for us to see what is happening here, and elsewhere, and hold these people to higher ethical standards than those to which they apparently hold themselves.

\section{Conclusion}

To this day, the lives of individuals, of communities, and of nations provide no lack of examples of "naïve justice," including the various permutations just described (viz. primitive justice or tribal justice). The problems of ethical philosophy would be very easy to solve with these kinds of axioms, uncritically applied, as they are by Socrates' interlocutors in Book I of Plato's Republic (Howland, 1993). The challenge posed to Socrates by Glaucon and Adeimantus at the beginning of Book II - to prove

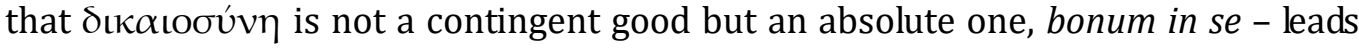
not only to the creation of the ideal city, but to metaphysical explorations that still resonate.

It would be difficult, if not ultimately impossible, to prove that all three of the authors discussed here, in the passages cited, are consciously contributing to the same discussion as Plato and Aristotle. The most important point to be made here, however, is not one of later authors borrowing from or alluding to the work of earlier authors, as interesting as this kind of study sometimes proves to be. The 
problem of $\delta \iota \kappa \alpha \iota \sigma u ́ v \eta$ is central to ethical discourse in Greek, and something very much like it, if variously worded, continues to be central. Children expect and even demand naïve justice in their stories: the good are to be rewarded, and the bad to be punished. Adults know, from experience, that life rather seldom presents us with such simple outcomes, in large part because determining what is right and what is wrong, in real situations, is seldom so clear cut. This, in turn, makes it very hard indeed to separate the good from the wicked, pace the legions of demagogues of right and left. As much as we may long for the clarity of naïve justice, it is only to be had at a price, which is closing our eyes to the complexity of the world we live in. The task of ethical philosophy is to confront that complexity, establish the axioms, identify the rules by which they can be applied to complicated situations, and provide us with something far more satisfactory, even if far more difficult, than naïve justice.

My contention here has been that these three trial scenes, for all the silliness that often surrounds them, send this message precisely. Despite the association with popular literature and the absence of academic credentials, we could do worse than to listen.

\section{References}

Primary Sources - Perseus Digital Library: http://www.perseus.tufts.edu/hopper/ (access: 1.03.2017)

Achilles Tatius, Leucippe and Clitophon.

Aristotle, Topics.

Aristotle, Poetics.

Chariton, Chaereas and Callirhoe.

Longus, Daphnis and Chloe.

Plato, Republic.

Secondary Sources

Anderson, G. 1982. Eros Sophistes: Ancient Novelists At Play. American Classical Studies. Oxford: Oxford University Press.

Howland, J. 1993. The Republic: The Odyssey of Philosophy. New York: Twayne Publishers. 
MacQueen, B. D. 1991. Myth, Rhetoric, and Fiction: A Reading of Longus's Daphnis and Chloe. Lincoln and London: University of Nebraska Press.

MacQueen, B. D. 2009. "Pleasure and instruction in the Prologue of Longus' Daphnis and Chloe." In: E. Wesołowska, K. Bartol, A. W. Mikołaczak \& T. Wikarjak (eds.) Delectare et docere. Symbolae Philologorum Posnaniensium XIX. Poznań, Poland: Adam Mickiewicz University Press.

Morales, H. 2004. Vision and Narrative in Achilles Tatius' Leucippe and Clitophon. Cambridge Classical Studies. Cambridge: Cambridge University Press.

Perry, B. E. 1967. The Ancient Romances: A Literary-Historical Account of Their Origins. Sather Classical Lectures. Berkeley, California: University of California Press.

Rohde, E. 1976. Der griechische Roman und seine Vorläufer. Leipzig: Verlag von Breitkopf und Martel.

Bruce D. MacQueen

(Tulsa, bruce-macqueen@utulsa.edu)

Naïve Justice in the Ancient Greek

Novel 
Abstract: This article discusses three trial scenes from three different ancient Greek novels (by Chariton, Achilles Tatius, and Longus), in which naïve justice seems to be deliberately subverted. The titular concept of "naïve justice" is defined here in terms borrowed from Aristotle's Poetics, where the term "double resolution" is used, disparagingly, of plots in which the good characters are all rewarded and the bad characters all punished. The argument is made that the trial scenes under discussion should raise doubts in the reader's mind as to which of the parties is truly guilty, and which is truly innocent. This can be seen as a reflection of unexpectedly mature ethical sensibilities on the part of these often-underestimated writers, who seem to have grasped that the "double resolution" may make the reader feel good, but has little to do with the real world.

Keywords: justice, moral ambiguity, ancient Greek novel, fictional jurisprudence, popular fiction

Ethics in Progress (ISSN 2084-9257). Vol. 7 (2016). No. 2, Art. \#3, pp. 14-30.

Creative Commons BY-SA 3.0

Doi: 10.14746/eip.2016.2.3 